4. On the Collection of Birds made by Prof. Steere in South America. By P. L. Sclater, M.A., Ph.D., F.R.S., and Osbert Salvin, M.A., F.R.S.

[Received January 3, 1878.]

\title{
(Plates XI.-XIII.)
}

At the request of Prof. J. B. Steere, of the University of Michigan, U.S. A., we have had great pleasure in examining the collection of birds which he made during his recent transit across South America, from Para to Callao, and in determining and naming the specimens.

In Nov. 1870, Prof. Steere went from Para first to Vigia, on the south bank of the Amazons, near the mouth, above fifty miles below Para. Returning to Para he next visited Arare, on the south side of the island of Marajo. On finally leaving Para for the interior, in June 1871, he ascended the river to Santarem, and from Santarem visited Obidos on the north bank. From Santarem he continued upwards to Manaos, or Barra, as it was formerly called, and thence made an excursion up the Purus river to Ituchy and Marrahan. Leaving Manaos in Oct. 1871, he ascended the main stream to Pebas, in Peru, where several skins, having the well-known " make" of Mr. Hauxwell (amongst which is a skin of Porzana hauxwelli, nobis), were procured. From Pebas Prof. Steere continued the ascent of the river to Barrancas and Pongo Manseriche, at the foot of the Andes, but returned downwards to the mouth of the Huallaga, and then ascended that stream to Yurimaguas, where he arrived in March 1872.

Here the voyage by steam came to an end, and Prof. Steere proceeded across country, via Tarapota, Moyobamba, Rioja, Chachapoyas, and Caxamarca, to the Pacific coast at Truxillo. From Truxillo Prof. Steere kept along the coast, viâ Pacasmayo to Sorritos ${ }^{1}$ and Tumbez, where, as will be seen by our notes, many of the local and interesting species of Western Peru were met with. From Tumbez Prof. Steere went to Guayaquil, and thence up to Quito and back. Next he proceeded to Lima by Callao, and made an excursion from the Peruvian capital up the Rimac and over the Andes, to the vicinity of Cerro de Pasco, returning finally to Callao. From Callao Prof. Steere sailed, in May 1873, for China and the Philippines, where he made those great discoveries in ornithology which have already rendered his name well known to ornithologists $^{2}$.

${ }^{1}$ Sorritos I do not find marked in the maps ; but Professor Steere tells us it is on the coast, about 20 miles south of Tumbez.

${ }^{2}$ See Mr. Sharpe's memoir in Trans. Linn. Soc. n. s. Zool. vol. i. p. 307 et seqq. (1877). 
During his journey across South America Prof. Steere made a collection of $91 \mathrm{l}$ skins of birds, belonging to about 362 species of the following groups:-

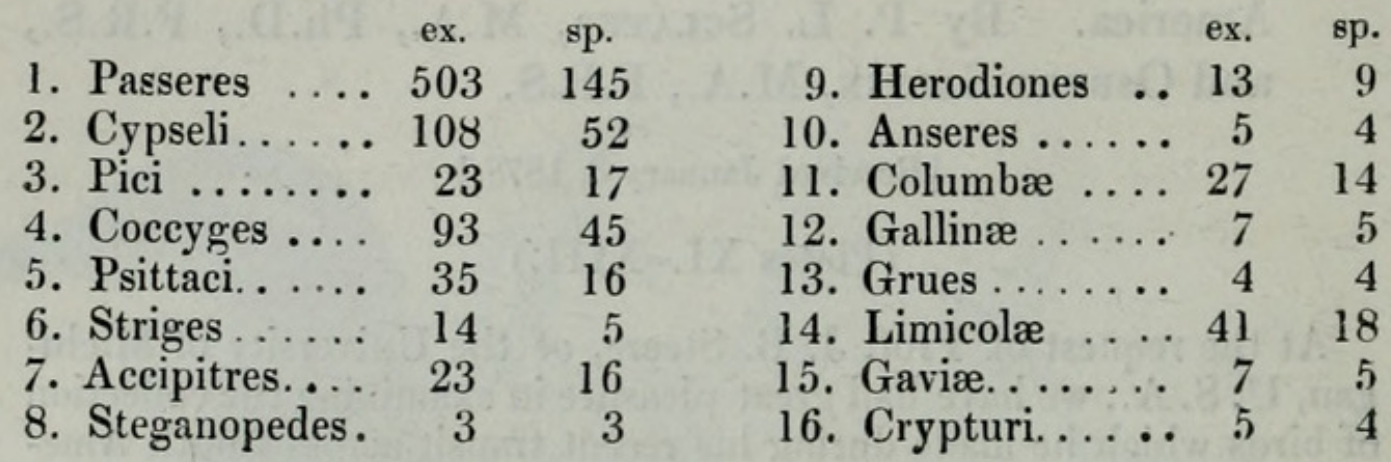

As might have been expected from the fact of Prof. Steere not having made a lengthened stay at any of the localities visited, the greater number of the specimens which he collected belong to well-known species, which we have named according to our 'Nomenclator Avium Neotropicalium.' But there are examples of twenty-two species amongst them, either unknown to us or otherwise of interest, concerning which we have the following notes to offer.

1. Oryzoborus atrirostris, sp. nov.

Ater aneo-nitens unicolor; remigibus primariis ad basin albis, speculum parvum tectricibus absconditum efficientibus; rostro crasso, nigro; cauda paulum rotundata: long. tota $6 \cdot 0$, ala $2 \cdot 9$, cauda $2 \cdot 7$, tarsi $0 \cdot 75$.

a

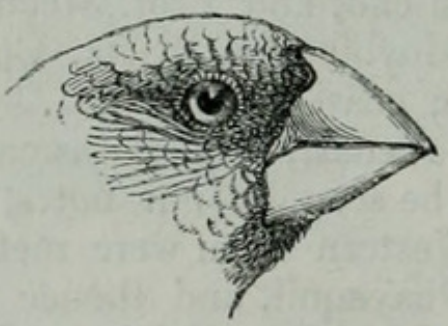

$b$

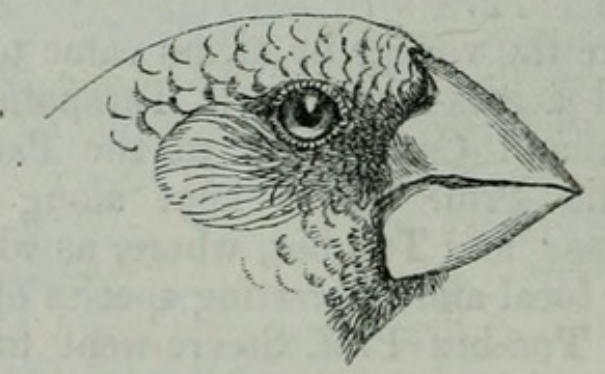

a. Head of Oryzoborus crassirostris.

$b$. Head of $O$. atrirostris.

Hab. Moyobamba, Peru (Steere).

Obs. Ab O. crassirostri et affinibus rostro robustiore et nigro diversus.

This Oryzoborus, of which Prof. Steere only obtained a single example, now in the Museum of the University of Michigan, is quite new to us ${ }^{1}$. It is readily distinguishable from $O$. crassiros-

1 Sporophila othello, Bp. Consp. i. p. 498, ex Am. Centr. (Mus. Berol.) is unknown to us and indeterminable, unless the type is existent. 
tris and its representative forms (O. maximiliani, $O$. occidentalis, and $O$. melas) by its black bill, which, as will be seen by the outline given, is also more robust than in $O$. crassirostris.

There is a small white speculum, which does not extend onto the outer web of the three outer primaries, and is concealed by the greater coverts when in their natural position. On the under surface of the wing the white extends barely half an inch beyond the black under wing-coverts, and then passes into grey, and at the extremities of the feathers into black.

\section{Piezorhina cinerea, Lafr.}

Guiraca cendre, Prév. et Des Murs, Voy. 'Venus,' Ois. p. 209.

Guiraca cinerea, Lafr. Mag. de Zool. 1843, pl. 20 (subg. Piezorhina).

Camarhynchus cinereus, Gray and Mitch. Gen. B. ii. p. 369 ; Bp. Consp. i. p. 542 ; Salvin, Trans. Zool. Soc. ix. p. 491; Tacz. P.Z.S. 1877 , p. 321 .

MM. Jelski and Stolzmann first discovered the true habitat of this curious Finch, which, through an error of the Naturalists of the Voyage of the 'Venus,' had been assigned to the Galapagos.

Prof. Steere's series contains a single skin obtained in Dec. 1872, at Sorritos, in Western Peru. It is marked "male : eyes light hazel." It agrees in every respect with an example from Tumbez (Jelski) in Sclater's collection.

\section{Hamophila stolzmanni, Tacz.}

Hamophila stolzmanni, Tacz. P. Z. S. 1877, p. 322, pl. xxxvi. fig. 2 .

Of this recently described Finch, from the same district, Prof. Steere likewise obtained a single example at Sorritos, in Dec. 1872. It is marked " male : eyes hazel." The discovery of a typical Hamophila (of which the six previously known species are entirely confined to Central America) in Western Peru is a fact of the highest interest.

4. Gnathospiza raimondil, Tacz.

Gnathospiza raimondii, Tacz. P. Z. S. 1877 , p. 320 , pl. xxxvi. fig. 1 .

Of this peculiar Fringilline form Prof. Steere obtained four examples during his sojourn at Sorritos.

\section{Icterus grace-annÆ, Cassin.}

Icterus grace-annce, Tacz. P.Z. S. 1877, p. 323.

Prof. Steere's series contains two skins of this well-marked Icterus, described in 1867 by the late Mr. Cassin, from a single specimen in the museum of the Academy of Philadelphia, of which the exact locality was uncertain. The western sea-board of Ecuador and Peru, however, is its undoubted habitat, as the late Prof. James Orton 
obtained specimens at Machala, near Guayaquil, as recorded by Salvin (Ibis, 1874, p. 323). Jelski and Stoltzmann also found it at Tumbez, as recorded by Taczanowski, l.s. c.; and Prof. Steere collected two examples-one at Pacasmayo on the coast north of Truxillo, and the other at Tumbez.

\section{Cyanocorax mystacalis.}

Pica mystacalis, Geoffr. Mag. de Zool. 1835, pl. 34.

Cyanocorax mystacalis, Scl. et Salv. Nomencl. p. 39, et P.Z.S. 1876 , p. 272 ; Tacz. P. Z.S. 1877 , p. 323.

Cyanocorax ortoni, Lawr. Ann. Lyc. N. Y. xi. p. 166.

Of this fine species Prof. Steere obtained one example at Tumbez, where MM. Jelski and Stoltzmann also procured it. Having now, through Mr. Lawrence's courtesy, had the opportunity of examining the type of his $\boldsymbol{C}$. ortoni, we are able to state that our anticipation as to its identity with $\boldsymbol{C}$. mystacalis was quite correct. Prof. Orton's skin is labelled as having been obtained at "Zicapa, Peru, Oct. 22, 1874." It may be remarked, however, that, whereas in Prof. Steere's specimen the five outer pairs of rectrices are wholly white, in Prof. Orton's the pair next to the middle pair have the basal half blue and indications of like colour in the centres of the adjoining pairs. It is probably on some such specimen as this that $C$. bellus of Schlegel ${ }^{1}$ was established.

\section{Euscarthmus zosterops?}

A skin of a Tyrant, obtained by Prof. Steere at Moyobamba, so nearly agrees with $\boldsymbol{E}$. zosterops, Pelzeln, Orn. Bras. p. 173, that we are unwilling to separate it on the faith of a single specimen. But it is certainly larger in its dimensions ${ }^{2}$, has a rather shorter bill, and the edgings of the wing-coverts and secondaries are paler and more distinct.

\section{Orchilus ecaudatus (Lafr. et D'Orb.).}

A skin of this species from Rioja, Peru, seems to agree well with Sclater's example from San Esteban (P. Z. S. 1868, p. 631). D'Orbigny's original type was from Yuracares, Bolivia.

\section{Myiarchus semirufus, sp. nov. (Plate XI.)}

Suprà fuscescenti-cinereus; uropygio et alarum caudaque marginibus castaneis, remigum omnium et rectricum mediarum parte mediâ nigricante; subtìs ochraceo-rufus unicolor; rostro et pedibus nigris: long. tota. $7 \cdot 5$, alce $3 \cdot 4$, cauda $3 \cdot 3$, tarsi $1 \cdot 0$. Hab. Pacasmayo, Peru (Steere).

1 Cf. Scl. et Salv. P. Z. S. 1876 , p. 272.

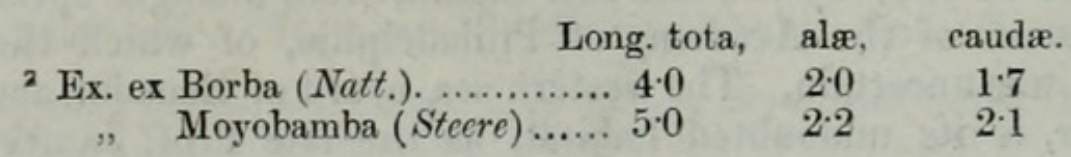


Although so abnormal in colour, we cannot arrange this bird, of which Prof. Steere unfortunately obtained but a single specimen, as otherwise than a typical Myiarchus. The wings are rather short, the third, fourth, and fifth primaries being nearly equal and longest. The wing-end, embracing the first five or six primaries, is black, as are the centre portions of the other remiges ; but the latter are bordered above and below with rufous. In the tail the black colour is confined to the inner webs of the three middle pairs of rectrices, the two outer pairs being wholly rufous, and the next pair having only a slight trace of the black patch.

\section{Macheropterus pyrocephalus, Sclater.}

Macharopterus pyrocephalus, Sclater, Ibis, 1862, p. 176.

Of this beautiful Manikin two examples were procured by Prof. Steere-one at Rioja, and the other at Moyobamba.

\section{Attila torridus, Sclater.}

Altila torridus, Sclater, P. Z. S. 1860, p. 280.

A single skin from Santa Rosa agrees with Sclater's types of his A. torridus, except in being rather brighter below and in being rather shorter in the wing. We do not think it distinguishable.

\section{Furnarius pileatus, sp. $\mathrm{n}$.}

Suprà castaneus, superciliis albis; pileo obscure brunneo; subtìs albus, lateraliter ochraceo perfusus; remigibus nigris rufo bifasciatis; rectricibus castaneis, macula in pogonio interiore nigrâ preditis; rostro corneo, mandibula inferiore ad basin albicante; pedibus nigris : long. tota $6 \cdot 8$, ala $3 \cdot 5$, cauda $2 \cdot 4$, tarsi $1 \cdot 1$.

Hab. Santarem, Amazons (Steere).

Obs. F. figulo affinis, sed pileo brunneo ed pedibus majoribus diversus.

A single skin of a Furnarius obtained at Santarem, on the south bank of the Amazons, seems to be referable to a representative form of $\boldsymbol{F}$. figulus, of S.E. Brazil, distinguishable by its dark brown cap. In $\boldsymbol{F}$. figulus the head is of exactly the same colour as the back. *

\section{Thamnophilus simplex, Sclater.}

Thamnophilus simplex, Sclater, Ibis, 1873, p. 387.

A single skin obtained at Vigia exactly agrees with Sclater's type of this little-known species, now in his collection. It is marked "male : eyes red."

\section{Steatornis Caripensis.}

A skin of this bird in Prof. Steere's collection is labelled as having been obtained at Caxamarca, in the Peruvian Andes. This, so far as we know, is much further south than any previously recorded locality 
for this wonderful bird. Since we examined this skin, Mr. C. Buckley has sent an example of Steatornis from Sarayacu on the Rio Bobonaza, a confluent of the Pastaza, in Ecuador, thus connecting Prof. Steere's Peruvian locality with those hitherto known for Steatornis in Columbia and Venezuela.

\section{Picumus sclateri, Tacz. P. Z. S. 1877 , p. 327.}

We are inclined to refer a skin of a Picumnus, obtained at Tumbez in December I872, to this recently described species, although in this difficult group an actual comparison of specimens is necessary to establish identity.

Prof. Steere's specimen is marked "male," but agrees with a bird described as a female by M. Taczanowski in having the head spotted with white. If, therefore, the sexes are rightly determined in both cases, it would seem that this species differs from most of its congeners in not having the head spotted with red or yellow in the male sex.

\section{Chloronerpes sedulus.}

Campias sedulus, Cab. et Hein. Mus. Hein. iv. p. 153.

Chloronerpes sedulus, Scl. et Salv. Nomencl. p. 99.

A "male" of this little known species was obtained by Prof. Steere at Obidos, on the Amazons. Sclater's collection contains a single female from Guiana; and the type described by Cabanis and Heine was of the same sex. The male, which is hitherto undescribed, differs from the female in having the feathers of the cap terminated with red instead of yellow.

The species is easily recognizable by the large well-defined pale yellow spots on the wing-coverts. Prof. Steere notes the eyes as "blood-red."

\section{Colaptes rupicola (Lafr. et D'Orb.).}

Colaptes rupicola, Scl. et Salv. Nomencl. p. 101.

A "female" skin from Cajamarca, which we refer to this species, differs slightly from skins obtained in Southern Peru by Mr. Whitely (see P. Z. S. 1869, p. 154) in having the spots on the chest produced laterally into narrow transverse bands. The rump and lower surface are likewise rather deeper in colour.

The label states that the bird is found " in the Upper Andes, among the rocks ; nests in mud walls ; eyes sulphur yellow."

\section{Capito steeriI, sp. nov. (Plate XII.)}

Suprà latè viridis, pileo vividè coccineo, nuchâ caruleâ; subtìs pallidè limonaceo-flavus, plagâ gulari et alterâ subpectorali coccineis; ventre viridi flavoque variegato; rostro plumbescente, tomiis et apice flavis; pedibus obscurè plumbeis: long. tota $5 \cdot 8$, ala $2 \cdot 8$, cauda $1 \cdot 8$, tarsi $0 \cdot 8$.

Hab. Moyobamba, Peru (Steere). 
Obs. Affinis C. richardsoni, sed colore corporis superioris pallidiore viridi, nuchâ cyaneâ, et pectore limonaceo-tlavo sanè diversus.

Of this beautiful new Capito, which we have the pleasure of dedito its discoverer, there is, unfortunately, but one specimen in the collection, now in the Museum of the University of Michigan. The species is closely allied in form and disposition of colour to $C$. richardsoni, but may be distinguished by the differences pointed out above.

Among some birds lately sent by Mr. G. N. Lawrence of New York to Sclater for determination, we find an imperfect skin, evidently of the same species. It was obtained by Walter S. Church at the "head-waters of the Huallaga," during his journey up that river, and belongs to the collection of the Smithsonian Institution.

\section{Columbula campestris (Spix).}

Five specimens of this species are in Prof. Steere's collection, all of them obtained at Arare, in the island of Marajo. The species, though long ago described by Spix, has seldom been met with by more recent collectors. Natterer, however, secured several examples, mostly in the Brazilian provinces of Goiaz and Cuyaba.

\section{Limosa fedoa (Linn.).}

Limosa fedoa, Scl. \& Salv. Nomencl. p. 146.

One of two specimens of this Godwit was obtained at Santa Rosa, Ecuador; the other is without precise locality. Though the allied L. hudsonica ranges throughout South America, this species, so far as we know, has not hitherto been noticed south of Central America.

\section{Xema sabinir, J. Sab.}

Xema sabinii, Coues, Birds of the North-west, p. 660 .

Prof. Steere's collection contains a single example of the Forktailed Gull, shot at Tumbez, Western Peru. This is the first instance of the occurrence of the species in any thing like so southern a locality, the limit of its southern range having been hitherto supposed to be the Great Salt Lake, Utah. The specimen is in adult winter plumage, the head being white, the nape and back of the neck ashy black, each feather with a very narrow white margin; the mantle is pure grey, and the primaries coloured as in the adult bird.

\section{Crypturus transfasciatus, sp. n. (Plate XiII.)}

Suprà ochraceus, dorso toto et alis extùs nigro transfasciatis; cervice posticâ murino-brunnea ; pileo nigro, ochraceo brunneo transfasciato; superciliis, gulâ et abdomine medio albis ; cervice imâ et pectore griseis; hypochondriis et tectricibus cauda inferioribus cervinis nigro transfasciatis ; rostro corneo, mandibula basi flavicante, pedilus flavis: long. tota 12 , ala $6 \cdot 2$, caude $2 \cdot 1$, tarsi $2 \cdot 9$, rostri a rictu $1 \cdot 5$.

Hab. Santa Rosa, Ecuador (Steere). 
Obs. C. variegato et $C$. bartletti forsan affinis, sed staturâ majore et pectore griseo distinguendus.

This apparently undescribed Tinamou has the back conspicuously transversely barred as in $C$. variegatus, but is much larger than that species and has the whole of the lower part of the neck brownish grey instead of cinnamon. C. bartletti, desciibed by us from specimens obtained by Mr. E. Bartlett in Eastern Peru (P.Z. S. 1873, p. 311), is also a smaller bird, and has the whole under surface except the throat fawn-colour; it also wants the light supercilium and the transverse marks on the occiput. In size the new species approaches $\boldsymbol{C}$. salla $i$; but the totally different colour of the under surface of this species renders further comparison unnecessary.

Prof. Steere's collection contains two specimens of this species, exactly resembling one another in colour, but differing slightly in size, the bird described above being the larger of the two.

\section{Note on the Anatomy of the Binturong (Arctictis binturong). By A. H. Garrod, M.A., F.R.S.}

[Received January 7, 1878.]

In an earlier communication ${ }^{1}$ I was able to confirm the observations of others, and to add fresh details, with reference to the anatomy of Arctictis binturong. Since that paper was published, two other specimens of the species have passed through my hands, the earlier of which differed in no respect from the one which $I$ had previouly described. The last, however, which died on January 4, 1878, presented a peculiarity which I feel to be deserving of record. It was a female, apparently adult, having lived in the Gardens of the Society since October 19,1875. The abnormal feature which it presented was the total absence of any trace of the colic cæcum, which, as is shown in a drawing accompanying my former paper, is normally extremely small.

The line of separation between the small and large intestines is well defined; and there is no valvular constriction between the two tubes, as is the case in the Arctoidea generally. There is a large Peyer's Patch quite close to the termination of the smaller gut.

The non-constancy of the presence of the diminutive cæcum in Arctictis binturong, and its total absence in Nandinia binotata ${ }^{2}$, makes it evident that the existence of the cæcum is a less important diagnostic character than was inferred by earlier investigators.

1 P. Z. S. 1873 , p. 196.

Vide Prof. Flower's "Note," P. Z. S. 1872, p. 683. 


\section{$2 \mathrm{BHL}$ Biodiversity Heritage Library}

1878. "On the Collection of Birds made by Professor Steere in South America." Proceedings of the Zoological Society of London 1878, 135-142.

https://doi.org/10.1111/j.1469-7998.1878.tb07941.x.

View This Item Online: $\underline{\text { https://www.biodiversitylibrary.org/item/90438 }}$

DOI: https://doi.org/10.1111/j.1469-7998.1878.tb07941.x

Permalink: https://www.biodiversitylibrary.org/partpdf/67222

\section{Holding Institution}

Natural History Museum Library, London

\section{Sponsored by}

Natural History Museum Library, London

\section{Copyright \& Reuse}

Copyright Status: Public domain. The BHL considers that this work is no longer under copyright protection.

This document was created from content at the Biodiversity Heritage Library, the world's largest open access digital library for biodiversity literature and archives. Visit BHL at https://www.biodiversitylibrary.org. 